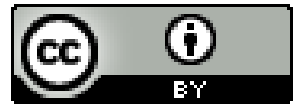

\title{
UMA PRETA MESTRA, UM ALTAR E SEUS ÍDOLOS: O COMÉRCIO COM A COSTA DA MINA E A RELIGIOSIDADE DA ANTIGA COSTAS DOS ESCRAVOS EM PERNAMBUCO, SÉCULO
} XVIII

Filipe Matheus Marinho de Melo ${ }^{1}$

Resumo: Este artigo discute um caso ocorrido em Pernambuco na segunda metade do século XVIII, onde africanos com procedência da África Ocidental se organizavam em roças nos arredores do Recife para dançar e festejar. A análise do caso relatado pelas autoridades coloniais, deixa entrever que as roças continham elementos da religiosidade da Antiga Costa dos Escravos e no episódio em questão o culto aos voduns eram encabeçados por uma mulher, identificada como preta mestra. $\mathrm{O}$ evento analisado permite entrever elementos de resistência e repressão que eram enfrentados pelos africanos, escravizados e libertos, como também inseridos em quadro simbólico maior que ligava as pontas do Atlântico através dos fluxos e refluxos que o comércio negreiro demandava.

Palavras-chave: Recife; Costa da Mina; comércio de escravos; religiosidade vodum; Século XVIII;

\section{A BLACK MISTRESS, AN ALTAR AND THEIR IDOLS: TRADE WITH MINA COAST AND OLD SLAVE COAST'S RELIGIOSITY IN PERNAMBUCO, $18^{\mathrm{TH}}$ CENTURY}

Abstract: This article discusses a case that occurred in Pernambuco in the second half of the eighteenth century, where Africans from West Africa organized themselves in roças around Recife to dance and celebrate. The case report, written by colonial authorities, shows that the roças contained elements of the religiosity of the Old Slave Cost, and that a woman, identified as a Black Mistress, headed its Voodoo Cult. The reported event allows a glimpse into the repression faced by Africans, enslaved and freed, as well as into aspects of their resistance, inserted in a larger symbolic framework connecting both sides of the Atlantic through the flow and reflow of the Slave Trade.

Keywords: Recife; Mina Coast; Slave Trade; Voodoo religiosity; 18th Century.

\footnotetext{
${ }^{1}$ Mestrando em História Social da Cultura pela Universidade Federal Rural de Pernambuco (UFRPE) e bolsista da FACEPE; licenciado em História pela Universidade de Pernambuco (UPE). E-mail: filipemarinhoo@gmail.com
}

Revista da ABPN • v. 12, n. Ed. Especial - Caderno Temático: "Africanos, escravizados, libertos biografias, imagens e experiências atlânticas” • agosto de 2020, p. $89-112$ 


\section{UNA MAESTRA NEGRA, UN ALTAR Y SUS ÍDOLOS: COMERCIO CON LA COSTA DA MINA Y LA RELIGIOSIDAD DE LA ANTIGUA COSTA DE LOS ESCLAVOS EN PERNAMBUCO, SIGLO XVIII}

Resumen: Este artículo analiza un caso que ocurrió en Pernambuco en la segunda mitad del siglo XVIII, donde la gente originaria de la África Occidental se organizó en roças alrededor de Recife para bailar y celebrar. El caso reportado por las autoridades coloniales muestra que las roças contenían elementos de la religiosidad de la Antigua Costa de los Esclavos, incluso el culto a los vodunes que estaba encabezado por una mujer, identificada como maestra negra. El evento nos permite percibir aspectos de la represión a que se enfrentaron los africanos, esclavizados y liberados, además de su resistencia, inserta en el marco simbólico más amplio que conectaba los extremos del Atlántico a través de los reflujos y flujos del tráfico de esclavos.

Palabras clave: Recife; Costa da Mina; tráfico de esclavos; religiosidad de los vodunes; siglo XVIII;

\section{UNE MAÎTRE NOIRE, UN AUTEL ET SES IDOLES: LE COMMERCE AVEC LA CÔTE DE MINA ET LA RELIGIOSITÉ DES ANCIENNES CÔTE DES ESCLAVES EN PERNAMBUCO, XVIII SIÈCLE}

Résumé: Cet article traite d'un cas survenu à Pernambuco dans la seconde moitié du XVIIIe siècle, où des Africains d'Afrique de l'Ouest se sont organisés dans des roças autour de Recife pour danser et célébrer. L'analyse du cas rapporté par les autorités coloniales montre que les roças contiennent des éléments de la religiosité de Anciennes Côte des Esclaves, et dans l'épisode en question le culte des vaudou était dirigé par une femme, identifiée comme maître noire. L'événement analysé permet d'entrevoir des éléments de résistance et de répression auxquels étaient confrontés les Africains, asservis et libérés, ainsi qu'insérés dans un cadre symbolique plus large qui reliait les extrémités de l'Atlantique à travers les flux et reflux qu'exigeait la traite négrière.

Mots-clés: Recife; Côte de Mina; traite négrière; religiosité vaudou; XVIII siècle;

\section{INTRODUÇÃO}

Esboçar aspectos de práticas religiosas africanas no Recife Setecentista é adentrar em terreno melindroso, dada a escassez de fontes. Quase tudo do que fora produzido sobre esses sujeitos, foi resultado do olhar do senhor, do governador, do padre, do viajante. Em vista disso, o que nos chega no presente são informações repletas de distorções, exageros e preconceitos, onde a violência e a desumanização são mascaradas através de preocupações que versam sobre o combate a feitiçaria, superstição e gentilidade e os envolvidos nos casos muitas vezes pagavam com açoites e outras violências variadas que só a mente humana é capaz de criar. No entanto, para além dessas questões, o que as

Revista da ABPN • v. 12, n. Ed. Especial - Caderno Temático: "Africanos, escravizados, libertos biografias, imagens e experiências atlânticas” • agosto de 2020, p. $89-112$ 
fontes nos informam - ainda que marcadas de juízos de valor - é que práticas culturais como as formas de religiosidade, as danças e os batuques, as práticas de cura, etc. se mostram como aspectos de resistência de sujeitos e grupos no seio de uma sociedade em que a proibição vedava o exercício pleno de práticas contrárias às hegemônicas.

O caso que trataremos nas páginas que se seguem só foi possível de emergir devido a uma questão maior que tinha se instaurado no Recife por volta de 1780 . O embate entre capuchinhos italianos, africanos de Angola e o então governador de Pernambuco, Jozé César de Meneses, em torno de batucadas e danças, nos possibilitou olhar para um episódio que fora fruto da repressão colonial: o da preta mestra. Por todo o episódio há diferenças e hostilidades que colocam as nações, organizações africanas na colônia, quase que como contrárias. Aos africanos de Angola, o governador sai em defesa; aos da Costa da Mina, há a repressão. No entanto, não acreditamos que houvesse no caso uma preferência da parte do governador, por uma ou outra nação, mas tão somente porque o exercício das práticas de uns parecia, aos seus olhos, serem mais inocentes e que não contrariavam os preceitos cristãos.

O caso da preta mestra, no entanto, é revelador. Infelizmente não sabemos seu nome, daí que utilizaremos os termos descritos na documentação. Também não sabemos se havia outras como ela ou se a própria era detentora do culto nos arredores do Recife. A menção feita pelo conde do Povolide, denunciador do caso, nos faz acreditar que era a própria que encabeçava o que, aos nossos entendimentos contemporâneos, parecia ser um terreiro de candomblé. O único elemento que iluminou o caso, portanto, e que nos ajudou a compreender melhor o episódio, foi a procedência dos envolvidos no culto, a saber, os pretos da Costa da Mina. Deste acontecimento tentamos extrair o máximo de informações que a fonte nos apresentava, localizando o caso em um contexto mais amplo que relaciona práticas culturais situadas em extremidades do Atlântico. Com isto não queremos indicar que houve uma transposição de elementos mágico-religiosos da África para a América, mas heranças que se deram no processo de fragmentação causado pela diáspora. As ligações realizadas entre o que fora encontrado no Recife e o que informa os estudos etnográficos sobre a Costa dos Escravos, são sobretudo hipotéticas, uma vez que a precarização das informações não nos permitiu avançar. 
Antes de adentrar no texto propriamente, alguns esclarecimentos. Estudos produzidos ao longo do século XX teriam relacionado a presença massiva dos africanos da Costa da Mina com a Bahia, induzindo que para o resto da América havia a hegemonia dos povos bantos da África Centro-Ocidental. Esta tendência teria apagado qualquer forma de relação de outras capitanias com a presença dos pretos minas. No entanto, pesquisas recentes sobre o comércio entre Pernambuco e a costa do continente africano, têm procurado mostrar que a região da costa ocidental era uma importante fornecedora de braços cativos para naus saídas de Pernambuco e que ao longo do século XVIII, embora as pressões da Coroa portuguesa insistissem no resgate nos portos de Angola, os brasílicos de Pernambuco iriam resgatar africanos na Costa da Mina em troca de tabaco, pipas de aguardente e ouro descaminhado. Nossa hipótese é que o comércio com a Costa da Mina se tratava de um comércio elitizado onde apenas alguns senhorios poderiam enviar suas embarcações, daí seu número diminuto. Também o fato da criação da Companhia de Comércio pelo marquês de Pombal, na década de 1750, onde estabelecia relações comerciais entre Pernambuco, Paraíba e Angola, permitiu supor que na segunda metade do século XVIII em diante, havia a presença hegemônica dos bantos vindos de Angola. Este trabalho, apesar de tratar de um caso essencialmente cultural, tenta brevemente contribuir para o olhar sobre a presença dos pretos minas na capitania, pois o constante desembarque de africanos da África Ocidental operou para construir um universo cultural e religioso em constante reconfiguração no Recife Setecentista.

\section{O COMÉRCIO ENTRE PERNAMBUCO E A COSTA DA MINA, SÉCULO}

\section{XVIII}

Dois eram os principais pontos de comércio para os negreiros de Pernambuco no século XVIII: Angola e a chamada Costa da Mina. O que se compreende como esta última é um extenso território da África Ocidental englobando os atuais países de Gana, Togo, Benim e parte oeste da Nigéria, situados no Golfo do Benim. O seu nome deveu-se a posição da feitoria portuguesa - o castelo de São Jorge da Mina (Elmina) - instalada naquela região para estabelecer comércio com os nativos, sobretudo os akan, onde os 
portugueses trocavam cativos por ouro. A Costa da Mina era subdivida em duas regiões cujos nomes derivam do principal comércio feito pelos europeus naquela região: Costa do Ouro, onde se situava Elmina, e Costa dos Escravos, a leste da fortaleza. Geograficamente, a região conhecida como "Costa dos Escravos" estendia-se do rio Volta até rio Lagos. Estima-se que a maior parte do contingente de cativos desembarcados no Brasil tinha como procedência a Costa dos Escravos. Os africanos provenientes dessa região eram comumente conhecidos por "pretos minas".

No entanto, não era novidade para os colonos de Pernambuco a presença dos africanos da região da Costa da Mina na Capitania. Em meados do século XVIII o cronista beneditino, Domingos do Loreto Couto, escrevia em sua obra Desagravos do Brasil e Glórias de Pernambuco, que um negro de nação arda, fugido e rebelado, tendo por nome Ganazumba, teria contribuído para a formação de Palmares, o quilombo. O curioso do caso é que "Ganazumba" estaria associado ao idioma banto, e não ao ewe-adja, falado pelos africanos naturais de Aladá, o reino do povo ardra. E o kilombo seria uma estrutura de origem da costa centro-ocidental. O cronista pode ter se equivocado ao indicar a nação ou, de fato, Ganazumba fosse de nação arda e este não seria um nome, mas um título (COUTO, 1904, p. 459). Também um século antes, o capitão dos negros, Henrique Dias, quando da expulsão dos holandeses da Capitania, informava que sua tropa de guerreiros era composta de "minas, ardras, angolas e crioulos" e completava: "os minas, tão bravos que onde não podem chegar com o braço, chegam com o nome; os ardras tão fogosos que tudo querem cortar de um só golpe" (OLIVEIRA, 1997, p. 62).

Desde o século XV havia um comércio na Costa do Ouro onde os portugueses atuariam como intermediários trocando cativos por ouro, inicialmente, e depois resgatariam alguns negros. É possível que os "minas", indicados por Henrique Dias não se tratasse dos cativos da Costa dos Escravos, da chamada área vodum ou gbé, mas dos saídos do castelo de São Jorge da Mina, possivelmente falantes akan, e que teriam sido introduzidos na capitania por comerciantes negreiros portugueses. Os ardras, por outro lado, podem ter desembarcado devido a algum conflito entre o reino de Aladá e os reinos da Costa do Ouro, gerando cativos para venda no mercado. Também no século XVII, quando Pernambuco esteve sob domínio holandês, a Capitania teria recebido africanos da 
região da Costa do Ouro, onde seriam também chamados de "mina". Vale lembrar que na década de 1630, os holandeses tomaram a feitoria de São Jorge da Mina dos portugueses e de lá teriam trocado mercadorias por negros e enviado para Pernambuco. Segundo dados de Robin Law, entre 1637 e 1645, cerca de 200 cativos da Costa do Ouro seriam escoados para Pernambuco, por ano, somando-se com os africanos dos portos de Aladá e da baía de Biafra, região a leste daquela costa, onde teria por principal porto Old Calabar (LAW, 2006, p. 117; SILVA, 2011, p. 203-213).

A partir de fins do século XVII e até meados do XVIII, o comércio entre Pernambuco e a Costa da Mina iria se intensificar por causa do tabaco de terceira, produto requerido pelos africanos daquela região, e também do ouro das Minas Gerais, que seriam descaminhados para as mãos de holandeses e ingleses. Neste interim, africanos mina seriam introduzidos na capitania em maior número que os africanos de Angola, posto que o tabaco não era um produto aceitável naquela região, como o era na costa ocidental. Sobre isto, o historiador Roquinaldo Ferreira, teria argumentado que um dos motivos para os deslocamentos dos baianos e pernambucanos de Angola para a Costa da Mina, seria porque seus produtos não teriam grande aceitação na região, além da concorrência com as mercadorias de comerciantes de Lisboa (FERREIRA, 2001, p. 341-344). De qualquer forma, segundo dados do provedor João do Rego Barros, entre 1722 e 1731, uma média de 22.220 africanos da Costa da Mina seriam introduzidos por cerca de 89 embarcações alojadas e arqueadas na praça do Recife, perfazendo uma média anual de mais ou menos 2.222 africanos entrando no porto de Pernambuco (AHU, Cx. 52, Doc. 3783). Segundo informações de Pierre Verger (1987, p. 48), quando analisou os passaportes dos brasílicos que iriam mercadejar na Costa da Mina, entre 1727 e 1737, cerca de 73 embarcações teriam saído de Pernambuco neste intervalo. Esses números, além de nos informarem que os portos da Costa da Mina eram demasiadamente atrativos para comerciantes negreiros situados na praça do Recife, nos permite entrever que a presença dos "pretos mina" na capitania seria algo comum.

Em meados do século tal situação iria mudar, principalmente por causa da formação da Companhia de Comércio Pernambuco e Paraíba (CCPP), criada pelo marquês de Pombal no ano de 1759. Já na década de 1730, devido ao intenso descaminho 
do ouro, a Coroa tentou minar as relações comerciais entre a praça de Recife e os portos da costa ocidental. Uma lei expedida pela Coroa portuguesa teria por pretensão diminuir a ida de brasílicos à Costa da Mina com o intuito de cessar a imposição da cobrança dos $10 \%$ feita pelos holandeses na Costa do Ouro - onde os brasílicos pagavam em ouro e tabaco fino - com o intuito de estimular o resgate nos portos de Angola, pois a fiscalização da Coroa seria mais precisa (VERGER, 2000, p. 22-23). Em 1731, o conde de Sabugosa, escrevia que com a proibição El-Rey desejava "evitar a extração do ouro (...) e tabaco fino que os ditos holandeses se utilizam" (AHU, Cx. 43, D. 3860). O intuito, no entanto, não era o de findar o negócio da Costa da Mina, mas de fazer cessar o descaminho do ouro e do tabaco de primeira qualidade que deveria seguir para a Metrópole. O resultado foi que parcela das embarcações ficaram proibidas de zarpar para Costa da Mina, reduzindo-as em números. Segundo indicou a pesquisa de Pierre Verger (1987, p. 48), se em 1727, foi encontrado 11 passaportes pelo autor, em 1737, dez anos depois, apenas 2 passaportes estariam listados. Para sintetizar tal questão, em 1732, o governador de Pernambuco lamentava: "quando tomei posse deste governo [de Pernambuco] havia 15 ou 16 embarcações que navegavam para a Costa da Mina (...) e que desta parte não tem mais que cinco" (AHU, Cx. 43, D. 3860).

A questão se estreitou ainda mais quando na década seguinte, de 1740, a Coroa ordenou que fosse realizado sistema de sorteio para conter ainda mais os números e evitar que algumas embarcações zarpassem mais do que outras. Nesse sentido, as embarcações estariam enquadradas no "giro", de onde deveriam partir em números limitados. A Bahia, no entanto, ainda que restrita ao giro, como Pernambuco, possuía mais embarcações disponíveis para fazer o mercadejo, além de seu tabaco ser o preterido naquela costa (ABN, p. 431-433; SOUZA, 2019, p. 120-121).

Somado a isto, desde que Agaja, rei do Daomé, teria finalmente se assentado no trono na Costa dos Escravos, no ano de 1732, iniciou-se naquela região um período de instabilidade, seguido de sucessivas guerras, seja com povos vizinhos, com os exércitos de mercenários contratados pelos reinos locais para depor o dadá, como também o reino de Oyó, situado mais a leste da região de Ajudá, de onde Savi, a capital do porto de Ajudá, seria tributária (SILVA, 2004, p. 49-51; MAIA, 2013, p. 87-88). Tal situação foi seguida 
de sucessivos reclames pelo vice-rei do Estado do Brasil e pelos diretores dos diferentes fortes europeus situados em Ajudá, por causa da baixa exportação de cativos daquela costa, assunto bem documentado por Pierre Verger (1987). Por outro, especificamente em Pernambuco, os senhores de engenho queixavam-se sobre a baixa na importação da mão de obra necessária para a produção do açúcar e alto preço dos africanos da Costa da Mina (AHU, Cx. 57, D. 4899).

Seja como for, criada a CCPP na década de 1750, se consolidaria uma relação comercial entre Pernambuco e os portos de Angola, onde todo o trâmite de mercadejo e de "resgate" de cativos, se daria na costa centro-ocidental. Devido a isto, o número de africanos de Angola para a segunda metade do século XVIII, seria superior se compararmos com os números de africanos vindos da Costa da Mina para a capitania, o que possibilitaria uma virada étnica na população africana. De acordo com nosso levantamento em livros de batismo, casamento, inventários e testamentos, encontramos um número de 970 africanos entre os anos de 1742-1800, onde 643 estariam identificados como de nação angola e 327 como de nação mina. Esses números, é claro, são apenas amostragens. Não seria errado dizer que tais números fossem bem maiores, uma vez que Pernambuco era o terceiro porto onde mais se desembarcava cativos na América portuguesa, atrás apenas da Bahia e do Rio de Janeiro, e o quarto das Américas (ALMEIDA, 2018, p. 2).

No entanto, a vinda de africanos da Costa da Mina não teria cessado. Embora o fluxo de naus entre Pernambuco e Angola fosse superior, algumas embarcações furavam esta rede para continuar o resgate com a costa ocidental. Em fins do século XVIII, se é registrado que entre 1761 a 1769, há pelo menos 14 viagens de naus saindo de Pernambuco para Costa da Mina (AHU, Cx. 110, D. 8507). Em 1777, duas embarcações, Natividade e Rozário Santo António e Almas, continuavam seguindo viagem para a costa ocidental africana com intuito de comprar cativos (AHU, Cx. 126, D. 9604). Fruto desse mercadejo, encontramos na década de 1790 uma série de batismos coletivos de africanos "do gentio da Costa", junto com os "do gentio de Angola" sendo batizados na Igreja de Santo Antônio, localizada na freguesia de mesmo nome, uma ponte apenas de distância da vila do Recife (AIMSSSAR, LB, fl. 146-148). O que nos aponta para uma continuidade 
no desembarque de africanos da Costa da Mina em Pernambuco na segunda metade do século XVIII, ainda que em números inferiores aos do começo do mesmo século.

Figura 1: A entrada no porto de Pernambuco e seus arredores

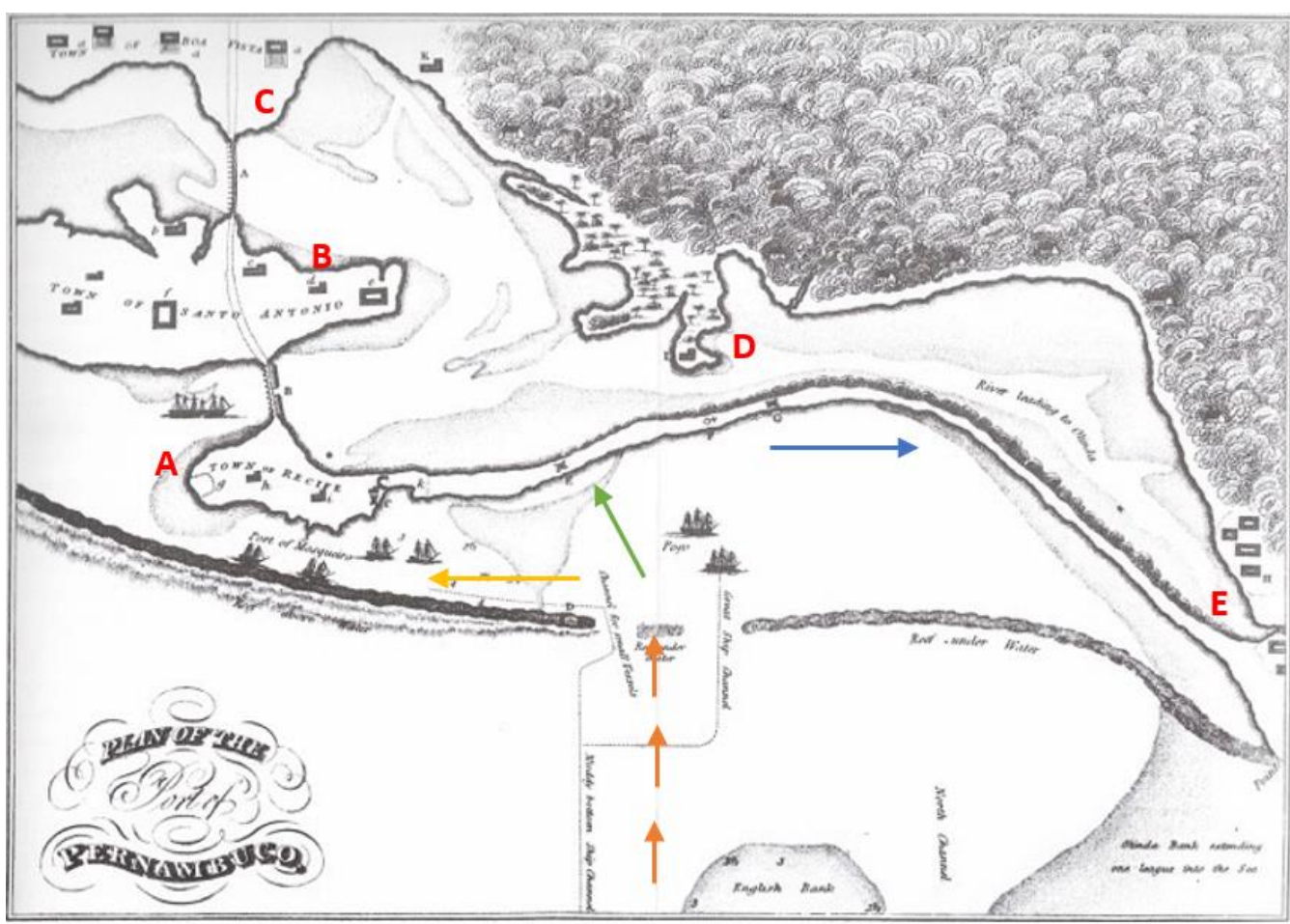

Legendas: A: Vila do Recife; B: Freguesia de Santo Antônio; C: Boa Vista; D: Santo Amaro; E: Olinda; Seta laranja: entrada no Recife; Seta verde: provável desembarque de pessoas; Seta amarela: desembarque de mercadorias; Seta azul: ida para Olinda por terra (istmo) ou água. Fonte: KOSTER, Henry. Viagens ao Nordeste do Brasil, vol. 1. Rio de Janeiro; São Paulo; Fortaleza: ABC Editora, 2003.

\section{A POPULAÇÃO "MINA" EM PERNAMBUCO E O CASO DA "PRETA MESTRA", SÉCULO XVIII}

Na segunda metade do século XVIII, a vila do Recife era um núcleo urbano densamente povoado. Estima-se que em 1775, a vila mais a freguesia de Santo Antônio, possuíam juntas cerca de 15.344 habitantes (COSTA, 1951, p. 536). Em 1788 esse número alcança os 21.539 habitantes (AHU, Cx. 178, D. 12472). Embora esses números sejam significativos, eles não nos permitem entrever o número da população escrava. Um censo de 1763, por outro lado, informa que a capitania de Pernambuco possuía por volta

Revista da ABPN • v. 12, n. Ed. Especial - Caderno Temático: "Africanos, escravizados, libertos biografias, imagens e experiências atlânticas” • agosto de 2020, p. $89-112$ 
de 90.397 habitantes, onde 38.565 seriam se refere a população de cor, indicada como pretos e pardos. Desse número, 24.432 eram indicados como "negros" (BN, mapas, fl. 2). Não seria improvável, portanto, que os africanos escravizados e libertos estivessem inseridos nestes números.

Em Pernambuco e em diversas regiões da América, os africanos se organizavam em torno de coletividades. Eram as nações, as irmandades, as corporações ou os cantos de ofícios que estruturavam as inter-relações entre os indivíduos a fim de desenvolver um sentimento de comunidade. A nação era a organização mais básica, pois ela moldava processos de identificações relacionais, onde o contraste, a diferença, mas também a semelhança, serviam como elementos aglutinadores ou dissipadores de sentimentos de grupo e pertencimento. Nesse agrupamento, identidades étnicas e uma miríade de significações culturais e sociais (como a língua, as escarificações, as vestes, a religião, o trabalho, etc.), serviam como elementos criadores de afinidades ou aversões, pois nem sempre laços de amizade e compadrio poderiam se dar de forma orgânica. Existiam as rivalidades que ou vinham d'África e eram reproduzidas em solo americano, ou mesmo as hostilidades existentes no âmbito colonial.

A documentação quando se refere aos africanos os identifica a partir de termos generalizantes que estão intimamente ligados com identidades impostas pelo comércio atlântico. Nesses casos, "mina" e "angola" são as nações mais comuns, pois era da região de Angola e da Costa da Mina de onde foram enviados diversos homens, mulheres e crianças escravizados para diferentes espaços no Atlântico. Estes termos, dessa forma, poderiam se referir aos portos de embarque, reinos, etnias e ilhas, como Cabo Verde, e muitas vezes não respondiam a uma identidade, ou seja, a autodenominações utilizadas pelos africanos em seus espaços de origem. Na colônia, estes termos de nações englobavam uma miríade de nomes étnicos ou de auto-identificação que poderia ser utilizada pelos africanos para nomear-se a si mesmos ou aos outros. No entanto, apesar desta generalização, alguns sujeitos ou grupos conseguiam utilizar identidades mais específicas que estivessem relacionadas com seus passados em África, como veremos mais adiante. 
Diversos estudos têm argumentado sobre o papel da nação com processos de identidade, seja interno ao grupo de africanos, como externo. Portanto, além da nação compor uma configuração interna, onde a relação entre os membros definiria a aceitação ou a recusa de um recém-chegado, também possuía sua atribuição externa, onde o comércio e as autoridades coloniais (agentes da alfândega, comerciantes, etc.) iriam ter sua parcela de contribuição na vida, vivência e identificação destes africanos. O processo identitário desses agrupamentos, portanto, funcionava de forma dual: tanto do ponto de vista dos africanos, inseridos em grupos majoritários (como mina ou angola), como dos grupos que inseriam estes indivíduos em grupos, nesse caso, as elites coloniais. Dessa forma, ainda que a diferença fosse a norma nas sociedades do Antigo Regime, era esta mesma diferença que criava os meios e os mecanismos para estruturar e localizar - inserir, portanto - os africanos nas malhas e hierarquias deste regime.

Sobre isto, Luis Nicolau Parés (2018, p. 25-26) sugeriu pensar em temos de entendimento "metaétnico", quando estudou dos candomblés de matriz jeje da Bahia. Para o autor, as formas de "auto-adscrição" (etnônimos), termo que pegamos emprestado de Maria Inês Cortês de Oliveira (1996, p. 175), e as imposições do comércio (metaétnico) parecem ter trabalhado juntas no processo de identificação dos africanos que, como afirmamos mais acima, se dava de forma dual. Nesse caso, a denominação metaétnica seria a imposição generalizante (mina ou angola), e que seria utilizada para assinalar um conjunto de indivíduos que compartilhassem traços comuns, sendo, sobretudo, uma forma de identificação externa ao grupo em questão. Os etnônimos, por seu turno, se referem às maneiras mais específicas de como os sujeitos agrupados em conjuntos metaétnicos se auto identificavam, ou seja, seriam denominações internas ao grupo (como ardra, massimba, nagô, savalu, etc.). Ainda segundo Parés, "as denominações metaétnicas (externas), impostas a grupos relativamente heterogêneos, podem, com o tempo, transformar-se em denominações étnicas (internas), quando apropriadas por esses grupos e utilizadas como forma de autoidentificação", também completa o autor que este conceito "é útil apenas para descrever o processo pela qual novas identidades coletivas são geradas a partir da inclusão" (PARÉS, 2018, p. 26). 
Como teria argumentado Carlos Francisco da Silva Júnior (2011, p. 20), esse conjunto identitário pode transparecer que se tratasse de identidades "verdadeiras" ou "falsas". Porém, a forma como um sujeito ou grupo tomava para si uma denominação de nação, partia de uma necessidade momentânea e específica, onde estas identidades poderiam ser acionadas, tanto do ponto de vista generalizante (mina ou angola), como do específico (ardra, dagomé, savalu). Portanto, os processos identitários não podem ser compreendidos como uma unidade acabada, mas a partir de multiplicidades, pois a identidade de sujeito varia de acordo com uma série de fatores, como o local onde se ele situa, o locutor que o invoca, a forma como ele se enxerga, etc.

No Pernambuco da segunda metade do século XVIII, a nossa pesquisa nos permitiu vislumbrar que dentro do guarda-chuva metaétnico "mina", havia uma miríade de etnônimos variados que serviam como formas de identidade assumidas pelos diferentes africanos no cotidiano. Como já destacamos, 327 seria o número de sujeitos inseridos na nação "mina” que pouco nos informa sobre aspectos mais específicos ligados com formas culturais diversas ou agrupamentos sociais. A tabela abaixo fragmenta em etnônimos o termo generalizante "mina".

Tabela 1 - Etnonimos do termo "Mina" em Pernambuco

\begin{tabular}{|c|c|}
\hline ETNONIMO & QUANTIDADE \\
\hline Ardra (ou arda) & 13 \\
\hline Calabary (ou calabar) & 7 \\
\hline Sabaru (ou savalu) & 1 \\
\hline Da gome (ou dagomé/daomé) & 1 \\
\hline Nagou (ou nagô) & 1 \\
\hline Courano & 2 \\
\hline Xamba (ou chamba/xambá) & 3 \\
\hline
\end{tabular}

Fonte: IAHGPE, fundo de inventários e testamentos, 1742-1800; APEJE, Patentes Provinciais (PP).

Estes números, apesar de diminutos, permitem entrever que havia uma diversidade de etnônimos na capitania em fins do século XVIII. O que fora indicado acima, trata-se de amostragem, como já afirmamos, pois a realidade poderia, além de ser mais diversa, conter peso mais significativo. Estes sujeitos estão arrolados nos inventários 
ou testamentos seguidos de seus nomes, nação, ocupação - em alguns casos - e preço. No caso das patentes doadas pelo governador José César de Meneses no ano de 1776, podemos vislumbrar apenas o nome seguido da nação, não informando condição, ou seja, se seriam libertos ou escravizados.

Com exceção dos "calabary", que teriam vindo do porto de Old Calabar, localizado na Baía de Biafra, e do nagô, que poderia ter sido capturado por guerras com o reino do Daomé ou ter sido comprado na região costeira do Benim pelos comerciantes brasílicos, e seria falante yorubá, grande parte dos outros teriam como procedência a região da Costa dos Escravos, também conhecida por área vodum ou área gbé, fazendo referência a religiosidade (vodum) e ao conjunto de línguas faladas naquela região, como fon, o adja, o ewé ou misturas destes falares (PARÉS, 2016, p. 43-44; 2018, p. 30-31). Tanto xambá como courano, teriam sido vítimas diretas de guerra contra o Daomé no litoral. Segundo Moacir Maia (2013, p. 70-72), os couranos (ou hulanos) teriam lutado contra o exército do dadá, por volta da década de 1740, com o intuito de não permitir que os daomeanos se assentassem no governo daquela região. Os xambás são descritos por Pierre Verger (1987, p. 167-168) e Edison Carneiro (2019, p. 62), como inimigos do dadá, estando envolvidos no rumor que ocasionou na prisão do diretor da feitoria portuguesa na década de 1730, pois João Basílio teria sido preso por supostamente fornecer armamento aos xambás contra o Daomé. Estes, segundo Valéria Costa (2011, p. 161), estariam situados em territórios diversos em África, dificultando sua precisão, além de serem falantes gur, não estando englobados nos grupos gbé da costa. Savalus possivelmente teriam sido vítimas de saques que eram empreendidos pelo daomeanos no interior para escoar seres humanos para o litoral. O reino de Savalu, aliás, ficava localizado a norte daquela região e fazia fronteira com o país Mahi (PARÉS, 2018, p. 3941). Dagomé, por sua vez, poderia ter sido enviado do porto de Ajudá ou arredores, como vítima de conflitos locais ou como punição. Os ardra, por terem sido encontrados em fontes que remetem a segunda metade do século XVIII, poderiam ter sido ou vítimas de guerras ou sujeitos vendidos na região de Porto Novo, a leste de Ajudá.

Os etnônimos sob a designação "mina” eram diversos, como se pode perceber. E, apesar de a segunda metade do século XVIII conter maior número da população africana 
de Angola, devido as ligações que o comércio negreiro estruturava, um olhar sobre a população da Costa da Mina, ainda que através de amostragens, nos faz perceber que havia uma pluralidade de sujeitos encobertos sob a designação "mina". Assim, tendo em vista tal diversidade, a partir de uma tentativa de aproximação, acreditamos que o caso que trataremos aqui está muito mais próximo do que a extensa bibliografia africanista histórica e etnográfica - têm associado com a Costa dos Escravos, pois o que fora descrito no episódio da "preta mestra" possui estreita ligação com elementos mágico-religiosos da área vodum. Infelizmente a descrição do episódio é curta e para dar corpo e sustentação à nossa análise descreveremos o processo de primeira leitura do caso, bem como nossas considerações sobre o mesmo.

No ano de 1778 desembarcava na vila do Recife um grupo de missionários capuchinhos italianos, possivelmente para ocupar a lacuna deixada pelos jesuítas, dada a ação do marquês de Pombal de expulsá-los das possessões portuguesas. Chegados e alojados em Pernambuco, os padres se escandalizariam ao ver nos centros urbanos os pretos que se "ajuntam e executam umas danças acompanhadas de ritos gentílicos (...) torpes e obscenos". Para conter "aqueles bárbaros" de executarem suas danças e cerimônias, os padres iriam se opor partindo para violência, pois invadiram a casa dos pretos, quebraram-lhes os instrumentos publicamente e decretavam a proibição das danças e ritos, sob a permissão do Santo Cristo. A estes pretos, os capuchinhos se referiam como sendo de nação Angola (RODRIGUES, 2019, p. 90). No entanto, a situação iria se estreitar porque o governador vigente, Jozé César de Meneses, iria intervir obrigando os padres a restituir os pretos em pagamento e ainda lhes ameaçando a expulsão da capitania, caso semelhante ação ocorresse novamente, pois que no lugar da força, contava o governador, os padres deveriam usar a persuasão (AHU, Cx. 135, D. 10140).

A ação do governador iria causar indignação do corpo eclesiástico da capitania a ponto do Tribunal da Inquisição, além do secretário de estado, Martinho de Melo e Castro, ter de intervir. No ano seguinte, em 1779, os capuchinhos enviariam carta ao Tribunal relatando o ocorrido. Diziam os padres que o governador estava mancomunado com os pretos de Angola, pois que além de não curar tal mal, ainda concedia licença para ocorrerem tais festejos em dias santos e aos domingos, como também quando padece 
"algum seu parente ou malungo", pois que colocam mesas e uma negra pedindo esmolas para se fazer rezar missas pela alma do tal malungo falecido e "se ajuntam uns aos outros de diverso sexo e à roda da mesa fazem uma dança ao modo de sua terra com uns atabaques e outros instrumentos fúnebres que, na verdade, não é outra coisa mais do que um rito seu gentílico”, informava o comissário Manoel Félix da Cruz. Após o quebraquebra, no mesmo dia os pretos de nação Angola foram reclamar junto ao governador o ocorrido, pois possuíam licença para se fazer os festejos. No dia seguinte, César de Meneses iria repreender os padres e os obrigar a ressarcir os pretos (que segundo consta, seria em cerca de 3 mil réis!). No mesmo ano, em 25 de novembro de 1779, escrevia ao governador o arcebispo de Lacedemonia, membro do Tribunal em Lisboa, queixando-se da ação para com os capuchinhos, pois que era a função do corpo eclesiástico não permitir tais males nas conquistas da El-Rey (RODRIGUES, 2019, p. 90-92; AHU, Cx. 135, D. 10140).

O governador iria retrucar, pois enviaria carta ao Tribunal, além de cópias para o secretário de Estado, Martinho de Melo e Castro. Informava o oficial que nas danças não havia nada de gentílico, pois se assemelhavam às fofas de Portugal, além de repudiar a atitude tomada pelos missionários, pois, argumentava em tom ácido: "não é próprio dos missionários tais procedimentos, e o que eu não devia permitir a pessoa alguma do meu governo (...) cuja obrigação e emprego deve ser o de instruir-nos e não só nos pontos da fé, se não na humildade e mansidão cristã". Também alegava, com cautela, que seria custoso para a paz da vila proibir o divertimento de homens e mulheres que trabalhavam penosamente nos ofícios da escravidão. O governador estava ciente que as danças, tão repudiadas pelos padres, seria uma forma de abrandar os ânimos dos escravizados africanos na colônia a fim de coibir um possível levante ou revolta (AHU, Cx. 135, D. 10140).

Para dar mais corpo ao caso, Martinho de Melo e Castro teria pedido conselho de um antigo governador de Pernambuco, o conde de Povolide. O conde teria argumentado a favor de César de Meneses, e informava "que ainda que [as danças] não sejam das mais santas, não as considero digna de uma total reprovação" e que em seu governo era comum "que os pretos divididos em nações, e com instrumentos próprios de cada uma, dançam e 
fazem voltas". No entanto, alertava o conde que o perigo não estava nestas danças, mas nas cerimonias conservadas em roças nos arredores do Recife, onde a presença de uma preta mestra, um altar e ídolos de barro, além de bodes e sangue de galos e diversos óleos para untar o corpo, eram seguidos também de danças, com bolos e festejos. Estes "bailes" que, segundo o conde de Povolide, eram praticados pelos africanos da Costa da Mina, é que eram dignos de total reprovação (AHU, cód. 583, fl. 221-222).

Infelizmente não dispomos de mais informações sobre o caso como localização ou maior detalhe sobre as "roças" dos pretos da Costa da Mina. De toda forma, o acontecimento merece uma análise pormenorizada. Ao nos depararmos com o caso em questão, nossa primeira interpretação estaria voltada para uma relação com as práticas de bruxaria europeia, em que as mulheres seriam protagonistas de sabás e ritualísticas várias que envolviam festejos sob a lua cheia, como teria estudado o historiador italiano Carlo Ginzburg (2012) e como depois Laura de Mello e Souza (2009) iria se ocupar com os casos de feitiçarias na Terra de Santa Cruz. No entanto, uma maior compreensão sobre "quem, afinal, eram os africanos minas?" na América portuguesa nos fez rever completamente nossa primeira percepção sobre o caso.

Uma segunda leitura do que teria indicado o conde de Povolide nos teria feito pensar em uma espécie de "calundu", como teria interpretado João José Reis (2016, p. 15) sobre o caso Magia jeje na Bahia, acerca de uma casa de culto de matriz religiosa africana encontrada pelas elites coloniais na região da Cachoeira. No entanto, segundo a análise do autor, "calundu" teria sido um termo encontrado na devassa sobre o acontecimento. "Calundu", portanto, já seria um termo corrente na época para se referir as casas como as encontradas pela polícia da Bahia naquela região. $\mathrm{O}$ conde, entretanto, utiliza o termo "roça" para se referir ao espaço de culto da preta mestra em questão. Como argumentou Vivaldo da Costa Lima (1976, p. 67), um dos significados atribuídos a candomblé estaria associado a terreiro, casa de santo e roça, pois, o significado teria se desprendido de "corpus ideológico do grupo (...) ao próprio local onde as cerimônias religiosas desses grupos são praticadas”. Este argumento nos teria levado a pensar não em uma organização de candomblé no século XVIII, mas em uma estrutura religiosa que possibilitasse aos africanos o exercício de práticas rituais aprendidas em África. 
Seja como for, para além do contato com o conjunto de documentos que discorreram sobre o caso, o dicionário de "língua geral da mina" produzido em meados do século XVIII por António da Costa Peixoto (1944, p. 18-29) nos chamou atenção por conter termos como "avóduno" e "Leba", significando, respectivamente, "padre" e "demônio". Em sua apresentação da obra, o autor deixa clara as intenções de seu texto, que tinham como objeto uma melhor compreensão da língua dos africanos na região de Minas Gerais com o intuito de controle ideológico. Ora, os escravizados que chegavam nas Gerais para serem utilizados para extração do ouro nada mais eram os "pretos minas" que vinham das naus de Pernambuco e Bahia, sendo escoados por terra - pelos sertões ou por mar - através do porto do Rio de Janeiro - para assim chegar nas regiões auríferas do Brasil colonial. Os mesmos africanos que seriam distribuídos para o resto da América a partir dos portos de Salvador e Recife, estariam frequentando estes centros urbanos, pois ainda que parte considerável fosse para Minas Gerais por causa do ouro, alguma parte ficaria na capitania.

Tendo isto em mente, nossa segunda trajetória de interpretação do caso se voltou para a literatura africanista histórica e etnográfica, pois não bastava compreender práticas culturais africanas na colônia em si mesmas, pois elas possuíam alguma conexão - ainda que fragmentária - com suas origens em África. Portanto, a contribuição dos estudos africanistas mais recentes, nos possibilitaram interpretar o caso em questão. Boa parte dos africanos sob o guarda-chuva metaétnico "mina", como vimos acima, tinham como procedência a região da Costa dos Escravos, espaço conhecido pelos cultos aos voduns, termo utilizado para se referir as divindades que até hoje são cultuadas nos países atuais de Gana, Togo e Benim. No tempo do comércio atlântico de escravizados, os reinos de Aladá, Ajudá e posteriormente o Daomé, cultuavam os voduns além de realizarem cultos domésticos específicos que possuía relação com os ancestrais. Luis Nicolau Parés (2016) em seu estudo sobre a religiosidade vodum na Costa dos Escravos, teria salientado como as práticas religiosas e as dinâmicas políticas e sociais naquela região da África Ocidental estariam imbricadas.

Para além das relações com a política e as regras sociais, as descrições ritualísticas e do panteão de divindades nos chamou atenção para o caso descrito pelo conde de

Revista da ABPN • v. 12, n. Ed. Especial - Caderno Temático: "Africanos, escravizados, libertos biografias, imagens e experiências atlânticas” • agosto de 2020, p. $89-112$ 
Povolide e para os africanos vindos da Costa dos Escravos, em termos gerais. Em primeiro lugar, tentamos desvendar os termos destacados por António Peixoto. Segundo o estudo de Parés (2016, p. 98-99), os termos “avóduno" e "Leba", registrados na obra de Peixoto, estariam ligados com elementos locais da Costa dos Escravos. "Vodunon" (ou boduños) significaria sacerdote e, segundo o autor (PARÉS, 2016, p. 100), os padres capuchinhos que visitaram a costa ocidental, relacionavam o termo com padre ou pelo menos "amigos de Deus", daí a assimilação feita entre avóduno e padre. "Leba", por sua vez, estaria relacionado com "Legba" uma divindade local que teria sido assimilada com o diabo cristão. Antes mesmo de Parés argumentar sobre o culto a este vodum, Pierre Verger (2000, p. 119-122) teria destacado que Legba seria o equivalente ao Exu dos yorubanos: "Elegba, divindade fálica no Sul, com o qual Esu teria tendência a identificarse", observou o autor.

A partir do entendimento de certas minúcias que relacionariam os "pretos minas" presentes na América portuguesa com os reinos da antiga Costa dos Escravos, percebemos que o caso da "preta mestra" não estaria associado com o imaginário da bruxaria europeia, mas com um exercício de práticas e ritualísticas africanas provenientes da área vodum da costa ocidental. A "preta mestra", portanto, seria uma vodúnsi, termo utilizado para se referir às sacerdotisas, ou como argumentou Nicolau Parés (2016, p. 98), “esposas do vodum" ou mesmo "devotas do vodum”. Estas seriam iniciadas e exerceriam cantos e danças relacionados com a divindade cujo culto estivesse sendo prestado. Portanto, mulheres, novas e/ou velhas, desempenhariam atividades religiosas de caráter exclusivamente feminino em contraste com as atividades masculinas. A relação entre a "preta mestra" e as danças que eram "dignas de total reprovação", nos permite mais uma vez relacionar aspectos do mundo da Costa dos Escravos com o caso encontrado e descrito em Pernambuco, pois danças estariam sendo praticadas na roças, como afirmou o conde de Povolide, onde parte da ritualística seria encabeçada por uma mulher. Estas roças, a propósito, poderiam ter alguma relação com as vódun xwé ou "casa do vodum" (PARÉS, 2016, p. 98), onde toda a ritualística de cultos aos ancestrais ou voduns seriam postos em prática, pois segundo conta o conde, os africanos se encontravam "as escondidas, ou em casas, ou roças" (AHU, cód. 583, fl. 221). 
Elementos do culto que foram encontrados pela mão repressiva do ex-governador também merecem análises. Segundo conta o documento, além da "preta mestra com altar de ídolos", esta e seu grupo estariam "adorando bodes vivos, e outros feitos de barro, untando seus corpos com diversos óleos, sangue de galo, dando a comer bolos de milho" (AHU, cód. 583, fl. 221). Nicolau Parés (2016, p. 97-98) conta que nos cultos observados pelos comerciantes e viajantes que estiveram na Costa dos Escravos entre os séculos XVII e XVIII, as reuniões religiosas eram regradas com bebidas e oferendas de cabritos e frangos em altares, onde depositava-se o fetiche, que faria suas revelações. $O$ fato de na roça em questão possuir bodes vivos e "outros feitos de barro", pode indicar a materialização de divindades representadas de forma antropomórfica. Pierre Verger (2000, p. 137) teria anotado um relato em que a representação de Legba, por exemplo, possuía chifres. "Fetiche", aliás, era o termo indistintamente utilizado pelos viajantes a uma miríade de elementos, desde comportamentos e objetos de culto até os próprios voduns, este último sendo a utilização mais comum e geralmente associada ao "ídolo" ou "falso deus" (PARÉS, 2016, p. 31). Nesses termos, a utilização de "fetiche", "ídolo" ou "falso deus", que seria marcada pelo imaginário cristão para associar e generalizar tais elementos com a idolatria ou gentilidade, e utilizada pelo conde de Povolide, oculta o fato de que tais instrumentos poderiam significar ancestrais materializados, objetos de culto onde haveria forças espirituais, como também a personificação da divindade.

Por outro lado, no que se refere aos usos de "bodes vivos" e "sangue de galo", citados pelo ex-governador, Parés não elabora maiores considerações sobre os usos destes animais na Costa dos Escravos, mas o uso do sangue para banhar os objetos no culto teria sido escrito pelo holandês Olfert Dapper em fins do século XVII: "um fetisero que vem imolar bois, carneiros e frangos e banhar de sangue seu fetissi” (apud PARÉS, 2016, p. 107). No entanto, também percebemos que há uma estreita ligação das aves e cabritos ou bodes com o que até hoje se executa nas festas de Tambor da Mina, nas casas de culto do Maranhão que são marcadas pelos cultos aos voduns. Segundo o estudo de Sérgio Ferretti (2011), tais animais fazem parte não só da "comida ritual" das diversas festividades realizadas pelos terreiros, como também elementos das oferendas, onde algumas delas, o 
"chibarro" e o "padê de Legba", seriam oferendas com bodes. As aves, por sua vez, são amplamente utilizadas, segundo o autor (FERRETTI, 2011, p. 254-262).

Como não seria de se estranhar, o caso em questão teria se findado com a dissolução da roça dos africanos da Costa da Mina. Segundo informou o conde de Povolide, os negros envolvidos foram castigados com açoites e remetidos para fora da capitania. Em casos de escravizados, foram vendidos. A dispersão, dessa forma, contraste da união, da coletividade, teria seu papel coercitivo. No entanto, o curioso é que no seio dos envolvidos, para além de africanos, estavam "padre e clérigos" que foram enviados para seus respectivos prelados para serem castigados, uma vez que não fazia parte da alçada do governador julgar pessoas da instância eclesiástica (AHU, cód. 583, fl. 222). A existência de padres, pessoas ligadas diretamente com os cultos católicos, nos faz pensar na dimensão que a casa da "preta mestra" teria alcançado nos arredores do Recife, algo que não podemos mensurar devido as parcas informações registradas. Dando sua opinião sobre o caso, o ex-governador, o conde de Povolide, pedia para que se diferenciasse as danças realizadas pelos africanos de Angola e as realizadas pelos da Costa da Mina.

\section{CONSIDERAÇÕES FINAIS}

Estima-se que cerca de 1 milhão de pessoas escravizadas teriam saído da Costa da Mina para o Brasil, entre os séculos XVII e XIX (PARÉS, 2016, p. 320). Para além da Bahia, lugar onde mais se concentrou e obteve o maior volume desses sujeitos através do comércio negreiro, estes africanos poderiam ser encontrados em outros espaços da América portuguesa, onde exerceriam suas práticas culturais e se (re) organizariam em torno da nomenclatura genérica imposta pela realidade colonial: nação mina. Dentre estes outros espaços, Pernambuco foi um deles. Como pessoas, estes indivíduos possuíam histórias pregressas, formas de pensar e agir que foram construídas em seus espaços de origem antes da diáspora imposta pelo comércio. Portanto, não seria exagero dizer que ao longo desse período, todo um arcabouço cultural e social, onde a língua, as formas de religiosidade, mas também as maneiras de se agruparem e de se enxergarem uns aos outros fossem articuladas com a realidade colonial. Daí que não há uma transposição da 
África para o Brasil, mas de elementos fragmentários que, aos poucos, foram marcadas pelo processo de ladinização, pela hibridez.

Até fins do século XVIII, portanto, os "minas" teriam sido majoritariamente os falantes gbé da Costa dos Escravos que se concentrariam nos centros urbanos e nas lavouras de açúcar e tabaco, além das minas de ouro, no Brasil colonial. Junto a eles, angolas, congos, beguelas, também nagôs e outros, contribuiriam para a formação de espaços plurais e dinâmicos, onde a cultura colonial e cristã, ainda que hegemônica, manteria diálogo com fragmentos das culturas africanas. Seja como for, concordamos com Nicolau Parés (2016, p. 322) quando este afirma que os agrupamentos dos falantes gbé no século XVIII, teriam montado um terreno, ou seja, agindo como modelo organizacional, para outras nações e contribuído para o desenvolvimento de manifestações culturais e estruturar socialmente os grupos que, aos poucos, adaptariam e se apropriariam destes espaços.

Sobre o caso da preta mestra aqui relatado, a "leitura para trás" proposta por João José Reis (2016, p. 14) quando revisitou Magia Jeje na Bahia, nos permitiu pensar as cerimonias nas roças não como manifestações idênticas aos agrupamentos de candomblé atuais ou até mesmo ligados com a realidade do século XIX, ainda que alguns elementos se conservassem. A realidade dos Setecentos era outra. Esta "leitura para trás" sugeriu olhar para o contexto africano e comparar elementos encontrados lá e cá, sempre dentro das possibilidades oferecidas ao pesquisador para não cair em anacronismos diversos. $\mathrm{O}$ próprio fluxo e refluxo continuado do comércio negreiro abria a possibilidade dessas roças adquirirem elementos novos e/ou rejeitar antigos, dada a assimilação ou rejeição de pessoas de lugares diversos. Tendo isto em consideração, tivemos o cuidado de não extrapolar nas hipóteses sobre o caso, nos mantendo no que o documento informava, tendo como base o que as pesquisas recentes ou não, sobretudo o que os textos de Pierre Verger e de Luis Nicolau Parés nos informou sobre aspectos da religiosidade vodum para os séculos XVII e XVIII, para não ultrapassar o recorte em questão. É provável que o caso tivesse se findado com a repressão do conde de Povolide, já que os açoites e expulsão da capitania estiveram na base de suas medidas repressivas. No entanto, sua observação sobre a necessidade de atenção aos africanos de Costa da Mina e o que fazem às 
escondidas, revela o quão outras formas de resistência desses grupos (e por que não de outros?) estavam por manifestar-se, mantendo viva e em constante renovação tradições culturais da África Ocidental em Pernambuco.

Apesar de pesquisas sobre o comércio e a presença dos africanos da Costa da Mina no Pernambuco colonial terem avançando nos últimos anos, muito precisa ser feito para destacar ainda mais o impacto demográfico e cultural destes sujeitos e de seus grupos no cotidiano da colônia.

\section{REFERÊNCIAS BIBLIOGRÁFICA}

ALMEIDA, Suely Cordeiro de. Rotas Atlânticas: o comércio de escravos entre Pernambuco e a Costa da Mina (c. 1724-c.1752). História (São Paulo), v. 37, 2018, p. 1-31. ANAIS da Biblioteca Nacional do Rio de Janeiro, v. 28, 1906.

Arquivo da Igreja Matriz do Santíssimo Sacramento de Santo Antônio do Recife (AIMSSSAR). Livro de Batismo, 1790-1792.

Arquivo Histórico Ultramarino (AHU), avulsos de Pernambuco, Cx. 43, D. 3860.

Arquivo Histórico Ultramarino (AHU), avulsos de Pernambuco, Cx. 52, D. 3783.

Arquivo Histórico Ultramarino (AHU), avulsos de Pernambuco, Cx. 57, D. 4899.

Arquivo Histórico Ultramarino (AHU), avulsos de Pernambuco, Cx. 110, D. 8507.

Arquivo Histórico Ultramarino (AHU), avulsos de Pernambuco, Cx. 126, D. 9604.

Arquivo Histórico Ultramarino (AHU), avulsos de Pernambuco, Cx. 135, D. 10140

Arquivo Histórico Ultramarino (AHU), avulsos de Pernambuco, Cx. 178, D. 12472

Arquivo Histórico Ultramarino (AHU), códice 583.

Arquivo Público Estadual João Emerenciano (APEJE), Patentes Provinciais (PP), toda a coleção: códices I a XII, 1774-1802.

BIBLIOTECA NACIONAL. Mapas Estatísticos de Pernambuco. Recife, 1763.

CARNEIRO, Edison. Ladinos e Crioulos: estudos sobre o negro no Brasil. São Paulo: Editora WMF Martins Fontes, 2019.

COSTA, F. A. Pereira da. Anais Pernambucanos, vol. 1. Recife: Arquivo Público Estadual, 1951.

Revista da ABPN • v. 12, n. Ed. Especial - Caderno Temático: "Africanos, escravizados, libertos biografias, imagens e experiências atlânticas" • agosto de 2020, p. $89-112$ 
COSTA, Valéria Gomes. Entre a África e o Recife: interpretações do culto Chambá. Revista da ABPN, v. 1, n. 3, nov. 2010 - fev. 2011, p. 157-180.

COUTO, Domingos do Loreto. Desagravos do Brasil e Glórias de Pernambuco. Rio de Janeiro: Officina Typographica da Biblioteca Nacional, 1904.

FERREIRA, Roquinaldo. A dinâmica do comércio intracolonial: geribitas, panos asiáticos e guerra no tráfico angolano de escravos (século XVIII). In: FRAGOSO, João; BICALHO, Maria Fernanda; GOUVEA, Maria de Fátima (org.). O Antigo Regime nos Trópicos: a dinâmica imperial portuguesa (séculos XVI-XVIII). Rio de Janeiro: Civilização Brasileira, 2001.

FERRETTI, Sérgio Figueiredo. Comida ritual em festas de Tambor de Mina no Maranhão. Horizonte, Belo Horizonte, v. 9, n. 21, abr./jun., 2011, p. 242-267.

GINZBURG, Carlo. História Noturna: decifrando o sabá. São Paulo: Companhia das Letras, 2012. Instituto Arqueológico, Histórico e Geográfico Pernambucano (IAHGPE), fundo de testamentos e inventários, 1742-1800.

KOSTER, Henry. Viagens ao Nordeste do Brasil, vol. 1. Rio de Janeiro; São Paulo; Fortaleza: ABC Editora, 2003.

LAW, Robin. Etnias de africanos na diáspora: novas considerações sobre os significados do termo "mina". Tempo, vol. 10, n. 20, 2006, p. 98-120.

LIMA, Vivaldo da Costa. O conceito de nação nos Candomblés da Bahia. Afro-Ásia, n. 12, 1976, p. 65-90.

MAIA, Moacir Rodrigo de Castro. De reino traficante a povo traficado: a diáspora dos courás do Golfo do Benim para as minas de ouro da América portuguesa (1715-1760). Tese (Doutorado em História). Universidade Federal do Rio de Janeiro, RJ, 2013.

OLIVEIRA, Maria Inês Cortês de. Quem eram os "negros da guiné"?: a origem dos africanos na Bahia. Afro-Ásia, n. 19-20, 1997, p. 37-73.

OLIVEIRA, Maria Inês Cortês de. Viver e morrer no meio dos seus: nações e comunidades africanas na Bahia do século XIX. Revista USP, São Paulo (28), dez. 1995/fev. 1996, p. 175-193.

PARÉS, Luis Nicolau. O Rei, O Pai e a Morte: a religião vodum na Antiga Costa dos Escravos na África Ocidental. São Paulo: Companhia das Letras, 2016.

PARÉS, Luis Nicolau. A Formação do Candomblé: história e ritual da nação jeje na Bahia. $2^{\mathrm{a}}$ ed. Campinas: Editora da Unicamp, 2018.

PEIXOTO, António da Costa. Obra Nova de Língua Geral da Mina. Lisboa: Agência geral das colônias, 1944.

REIS, João José. Revisitando "Magia Jeje na Bahia". In: GOMES, Flávio; COSTA, Valéria (orgs.). Religiões Negras no Brasil: da escravidão à pós-emancipação. São Paulo: Selo Negro, 2016.

Revista da ABPN • v. 12, n. Ed. Especial - Caderno Temático: "Africanos, escravizados, libertos biografias, imagens e experiências atlânticas” • agosto de 2020, p. $89-112$ 
RODRIGUES, Aldair. Malungos e parentes: "Sumário contra os pretos de Angola do Continente de Pernambuco" (1779). Sankofa: Revista de História da África e da Diáspora africana, ano XII, n. XXII, maio/2019, p. 63-92.

SILVA, Alberto da Costa e. Francisco Félix de Souza, mercador de escravos. Rio de Janeiro: Nova Fronteira; EdUERJ, 2004.

SILVA, Alberto da Costa e. A Manilha e o Libambo: a África e a escravidão, de 1500 a 1700. $2^{\mathrm{a}}$ ed. Rio de Janeiro: Nova Fronteira, 2011.

SILVA JUNIOR, Carlos Francisco da. Identidades afro-atlânticas: Salvador, século XVIII (17001750). Dissertação (Mestrado em História). Universidade Federal da Bahia, Salvador, BA, 2011.

SOUZA, George Félix Cabral de. Comerciantes de escravos em Pernambuco (c. 1660 - c. 1760): aproximação a um grupo mercantil colonial. Clio: revista de pesquisa histórica, vol. 37, jul./dez., 2019, p. 115-143.

SOUZA, Laura de Mello e. O diabo e a terra de Santa Cruz: feitiçaria e religiosidade popular no Brasil colonial. São Paulo: Companhia das Letras, 2009.

VERGER, Pierre. Fluxo e Refluxo do tráfico de escravos entre o golfo do Benin e a Bahia de Todos os Santos dos séculos XVII a XIX. São Paulo: Corrupio, 1987.

VERGER, Pierre. Notas sobre o culto dos Orixás e Voduns na Bahia de Todos os Santos, no Brasil, e na Antiga Costa dos Escravos, na África. São Paulo: Editora da Universidade de São Paulo, 2000.

Recebido 03/07/2020

Aprovado em 22/07/2020

Revista da ABPN • v. 12, n. Ed. Especial - Caderno Temático: "Africanos, escravizados, libertos biografias, imagens e experiências atlânticas” • agosto de 2020, p. $89-112$ 